
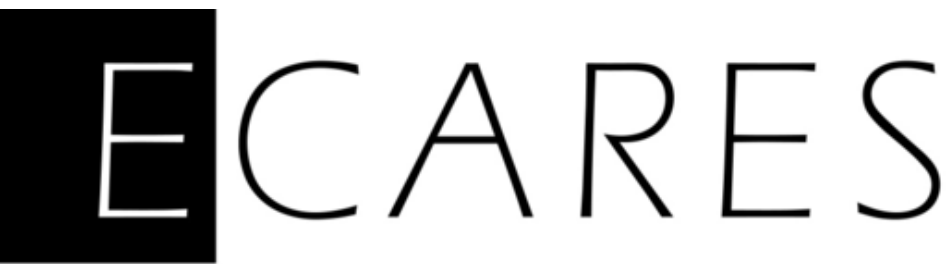

\title{
Intra-Country Distributional Impact of Policies to Fight Climate Change: A Survey
}

\author{
Dorothée Boccanfuso \\ GREDI, Université de Sherbrooke, Canada \\ Antonio Estache \\ ECARES, Université Libre de Bruxelles \\ Luc Savard \\ GREDI, Université de Sherbrooke, Canada
}

ECARES working paper 2008_038 


\title{
Intra-country distributional impact of policies to fight Climate Change: A survey
}

\author{
DOROTHÉE BOCCANFUSO*, \\ ANTONIO ESTACHE ${ }^{i}$, \\ LUC SAVARD**
}

\begin{abstract}
In this paper we present a survey of distributional impact analysis of environmental policies envisaged or implemented to reduce greenhouse gaz emissions. The implementation of these policies usually aim at reducing greenhouse gases directly or indirectly. However, these policies can also produce important changes in factor allocation, relative prices in specific countries as well as on world markets when these policies are adopted by a large number of countries. The changes in welfare can be important for vulnerable groups of population in developing countries. This survey reviews the evidence on the incidence of these policies. In the process, it shows that the computable general equilibrium (CGE) microsimulation approach has not been fully exploited in the context of distributional impact analysis of CC policies.
\end{abstract}

Keyword: Global warming, environmental policies, income distribution, developing countries.

JEL：D58, D60, H23, O13, Q52

\footnotetext{
* GREDI, Department of Economics, Faculté d’Administration, Université de Sherbrooke, Sherbrooke Canada

${ }^{`}$ European Centre for Advanced Research in Economics and Statistics, Université Libre de Bruxelles.

** Corresponding author, GREDI, Department of economics, Faculté d'administration, Université de Sherbrooke, Sherbrooke Canada (luc.savard@usherbrooke.ca)
} 


\section{Introduction}

Awareness of the potentially catastrophic consequences of climate change is leading governments across the world to consider a wide range of drastic policy actions at the international level resulting in commitments to deliver actions at the national level. There is a great deal of discussion on the share of the global burden that developed and developing countries will have to take on (see Toman and Burtraw 1992, Carzola and Toman 2000 and Tol et al. 2004, among others). Equity is an integral part of global climate change (CC) policy and the 1992 United Nations Framework Convention on Climate Change (UNFCC) reflects this by declaring that the responsibility of actions across nations should follow the principle of common but differentiated responsibility. However, there is very little debate on the distribution of this share within countries and more specifically within developing countries. ${ }^{1}$ This debate should deal with both adaptation and mitigation. Indeed, although adaptation is currently benefiting from the limelight in the international community (See IPCC 2007 and DFID 2004), the design of mitigation policies in the context of many very basic services continues to be a cornerstone of CC related policies. For instance, access rates to basic energy services are still so low that the investment needs of the sector and their financing should continue to be central policy concerns in over $50 \%$ of the countries of the world.

The challenge is however to build in the fact that the participation of developing countries in stabilising greenhouse gases (GHG) is also important to multilateral efforts to address the problem. Developing countries already account for half of annual global greenhouse gas emissions, and future GHG growth will mainly come from developing countries (Jotzo 2004). According to the United Nations, the adjustments required in addressing CC concerns in lower

\footnotetext{
${ }^{1}$ Tol (2001) states that equity has rarely been addressed in CC policy reform analysis. Since 2000, several studies have integrated equity criteria in their analysis but very few, as we will demonstrate, are applied to developing economies.
} 
and lower middle income countries demand expenditure commitments of about $0.5 \%$ of gross domestic product (GDP) annually for the foreseeable future. The Intergovernmental Panel on Climate Change (IPCC) also estimates the costs of mitigation needed to achieve a 450ppm $\mathrm{CO}_{2}$ stabilization target (i.e. the costs of financing technological change and substitutions to reduce inputs and emissions per every unit of output) at about $1.6 \%$ of GDP. This means that the equivalent of an additional 2.1\% of GDP will have to be funded from new or existing sources (UNDP 2007).

Most of these mitigation costs will have to be financed through increases in old taxes (such as motor vehicle taxes), new taxes and equivalent revenue raising instruments (such as betterment taxes) or levies in order to capture some of the property value changes resulting from the policies. In many countries, some of the new costs will also be financed through improvements in cost recovery of public services. The reforms proposed involve an internalization of the negative externalities generated by GHG. These policies will directly and indirectly contribute to increasing the production costs and market prices of goods that contribute to global warming.

But concern about the incidence of CC policies is not only needed for ethical reasons. It is also important in ensuring the social acceptability and hence the political viability of reforms, which tend to be higher with progressive reforms than with regressive ones. For instance, according to Serret and Johnstone (2006), the proposed Btu tax in the United States and the petrol duty escalator in the United Kingdom were rescinded or reformed in part for their anticipated regressive distributional effects.

As stated by Markandya (1998), understanding the links between environmental policies and their distributional impact is an essential part of undertaking distributional impact analysis. 
Markandya also insists on the necessity of taking into consideration the policies of developed countries and their impact on income distribution in developing countries. Verbruggen, Kuik and Bennis (1995), for example, show how environmental regulations associated with exports to European countries have influenced producers and exporters of Kenyan cut flowers and especially the revenues of the most vulnerable producers. The identification of the winners and losers and the effects on distributions of revenues of populations and of certain particularly vulnerable groups are important elements to consider in the analysis of distributional impacts of environmental policies, as Markandya (1998) points out.

The objective of this paper is to review the literature on the impact of CC related policies on income distribution in developing countries. We begin by presenting the main links between CC policies and income distribution. Since the literature is relatively scarce in this specific area, we follow with a broader overview of the literature on the welfare impact of environmental policies. We then focus on applications of computable general equilibrium (CGE) modelling of the impact of environmental policies on income distribution. We cover the evidence for both developed and developing countries. We conclude with some recommendations for future research.

\section{Links between CC policies and income distribution}

The main objective of CC policies is to reduce GHG. Various policies can be used to achieve this goal. Any of the policy options will have indirect impacts often ignored by the primary assessments of their effects. In general, environmental policies are ideally assessed with a number of criteria such as economic efficiency, equity, administrative and compliance cost and dynamic impact on innovation and public acceptability. As stated by Tol (2001), most studies 
have focused only on economic efficiency. Serret and Johnstone (2006) highlight the fact that most economists are more comfortable with the "Pareto Superiority" concept which implies that a good policy is one that improves the welfare of all agents. But as Kriström (2006) states, almost all policies will produce winners and losers, and policy makers should be concerned with this issue. The Kaldor-Hicks criterion provides guidance for policy relevance of reforms by stating that a policy is welfare-improving if the sum of the benefits is greater than the total cost and the winners can compensate the losers (Johansson 1993). In this context, a process is required to identify the winners and losers in CC policies. Moreover, in the context of developing countries, if the CC policies are regressive and affect large portions of vulnerable population groups, the implementation of environmental policies to reduce GHGs could conflict with the achievement of at least some of the millennium development goals (MDGs). Hence, taking appropriate measures to compensate the losers in this process is even more important when considering the poverty context of developing as opposed to developed countries. ${ }^{2}$

Most incidence analysis performed to date has focused on the direct effect of CC policies on income distribution. This direct effect is observed through the change in price of goods targeted by the policy. The relative importance of the targeted goods in the consumption basket of the poor is the key element in this equation (Serret and Johnstone (2006)).

But it is essential to also consider the numerous indirect effects that also play a role in determining the ultimate distributional impact of a policy. One key such indirect impact is the increase in cost of energy inputs for production of other goods. The changes in market prices of

\footnotetext{
${ }^{2}$ While the concern with the incidence of CC related policies is thus clearly essential, it is just as important to recognize that the benchmark used to compare this incidence should be the long-term consequences of the failure to act. Ignoring the consequences of CC is widely expected to be significantly more regressive in developing countries than in developed countries. For instance, up to $80 \%$ of the world's poorest populations rely on much more health-damaging energy sources for their immediate needs than for longer term strategic concerns. Policy intervention thus seems to be the only ethical option when considering the world's poorest.
} 
goods and cost of inputs for other goods introduced in the economy due to changes in the price of this key input will significantly modify factor allocation and factor payments in the different sectors of the economy. Hence, factor payments such as capital payment and wages will change and play a significant role (Fullteron and Heutel 2007). The volume and quality of employment could potentially be affected (McColloch et al (2002)) ${ }^{3}$. According to the OECD (2003), employment impact can have larger distributional effects than those of distributional price effects.

The fiscal incidence of a policy can also contribute to the modification of income distribution if the CC policy is non neutral for government revenues. An increase or decrease in income will allow the government to increase or decrease expenditure, and this can favour poorer households versus richer households or vice versa (Serret and Johnstone 2006).

The institutional context of developing countries presents an additional challenge. Given the weak capacity of governments to implement and collect new taxes, these policies will involve a significant increase in administrative costs not faced by developed (OECD) countries.

Moreover, exports could decrease with loss of competitiveness and further reduce the demand for labour and/or capital. If the poor represent a large share of the workers in the sectors concerned, they will be hurt by the environmental effects and tax, and disproportionately so.

In fine, the microeconomic burden of these measures will depend on many factors, including natural resource endowment, factor endowment, structural characteristics of the economies, consumption and country trade pattern. Moreover, the impact of policies will not be confined to the country where they are applied. If a country with a large economy or a large

\footnotetext{
${ }^{3}$ McColloch et al. (2002) provide an interesting and detailed review of transmission mechanisms between trade reforms and poverty and household welfare. Since CC policies aim to modify relative prices in the economy, as do trade reforms, these transmission mechanism are quite similar. According to Kriström (2006) the impact of changes in labour quality and quantity following a CC policy has rarely been dealt with in distributional analysis.
} 
number of countries simultaneously implements similar policies or policies having the same effect on prices, the impact will be felt on world markets of goods directly or indirectly concerned by the policy. Hence, world demand, supply and prices could be significantly affected. For any government concerned with the well-being of the poor or the fair distribution of the burden of policies, the assessment of the ultimate incidence of any CC policy is thus a necessity.

As stated by Kriström (2006), the large adjustment in prices due to CC policies is likely to succeed in changing at least some consumption and production decisions. In addition, CC policies such as carbon taxes will generate the revenue required to finance the investments needed to address transitional adaptation and mitigation costs. This is consistent with the objectives of environmental policies. Taxes, fees and public services tariffs increases and rebalancing are needed to increase awareness of risks and hence change consumer and investor behaviour with respect to CC. They also need to ensure that the awareness of risks associated with CC is transformed into concrete actions and not just commitments to act. Yet the incidence of many of these sources of revenue is hard to track down precisely.

The risks are however clearly stronger for the poor in developing countries since developing countries are most exposed and vulnerable to climate change (UNDP 2007) because these countries have to deal not only with the consequences of their policies but also with the consequences of the policies of developed countries. For example, CC policies contribute to increases in costs of energy and natural resources and this will affect global energy prices. Also, 
ceteris paribus, strong increases in green taxes could reduce world supply and demand of goods directly or indirectly concerned ${ }^{4}$.

The evidence suggests that the sectors most strongly affected by GHG emission reduction policies are the energy, natural resources and agricultural sectors. This is dramatic for many developing country economies since they are dependent on food and energy imports and export mostly agricultural goods and natural resources. We can therefore assume that they are extremely vulnerable to important demand and price changes on the world market for these goods. But the risks to the most vulnerable do not stop there. Indeed, the poorest and most vulnerable groups in developing countries are concentrated in the agricultural sectors and agricultural goods constitute a large portion of their total expenditure. This is why the voices of concern over the negative impact of increasing prices for food staples on the welfare of vulnerable groups in developing countries are so loud and increasingly so. ${ }^{5}$

\section{Modeling the distributional impact of CC and environmental policies}

This section organizes the overview of the evidence on the distributional effects of CC and environmental policies according the methods used to assess the incidence. It covers very basic approaches such as partial equilibrium analysis or input-output analysis as well more advanced methods, including various generations of computable general equilibrium models.

\footnotetext{
${ }^{4}$ It is important to highlight that the effects on world markets for food staples, natural resources and energy are taking place simultaneously with other factors such as the strong growth of the world economy.

${ }^{5}$ Important non-governmental organizations such as OXFAM and Friends of the Earth have taken a strong stance against the promotion of biofuels, as their consequences on poor populations of developing countries could be disastrous (Oxfam 2007). But more academic researchers have covered many of the same issues: Ivanic and Martin 2007, Doornbosch and Steenblik 2007 and Wodon et al. (2008).
} 


\subsection{The partial approach}

The initial sets of studies on the regressive nature of these environmental taxes were based on partial-equilibrium models which assume both that these taxes are directly paid by consumers and that they do not impact the prices of other goods. These models already suggest that if taxes on energy goods increase, poor households will be affected the most. The results cannot be robust since they ignore any type of retroactive or feedback effects.

\subsection{The input-output method}

The initial studies documenting feedback effects were often based on input-output (I-O) analysis and, more recently, on analysis of multipliers in the social accounting matrix (SAM). These simulation models are based on fixed prices and coefficients, and tend to focus on demand. Effects can be measured across the entire economy and can be disaggregated in such a way as to take into consideration different sectors of activity, the government and consumers. ${ }^{6}$ These models are also been used to analyse the impacts of environmental policies (Leontieff, 1970; Isard et al., 1972; Pan and Kraines, 2001; Berck and Hoffmann, 2002).

Even if they are a significant improvement over partial equilibrium models, they have their own share of problems. One of the limitations is the difficulty of establishing effects with regard to supply. Any change in the level of a particular branch of activity translates into a proportional change of all inputs used in the branch. This is a direct result of the fixed-coefficient hypothesis and of linearity.

Some authors have developed an approach based on the combination of microsimulation models with input-output tables (Symons, Proops and Gay, 1994; Cornwell and Creedy, 1996; Labandeira and Labeaga, 1999; Wier et al., 2005) and argue that this approach is more

\footnotetext{
${ }^{6}$ For a detailed presentation of this approach, see Bulmer-Thomas (1982) and Miller and Blair (1982).
} 
comprehensive than simple input-output analysis. First, the effects of an environmental tax on an I-O demand model are calculated; then, the effect on households as well as the reactions of these households are analysed using a microsimulation model.

However, this methodology creates other problems, since its analysis is based on partial equilibrium and, because the analytical framework is static, it is impossible to take agent reactions into account (Labandeira, Labeaga and Rodríguez, 2006). A number of authors consider that general-equilibrium modeling is better adapted, as it avoids this problem (Kriström, 2006; Roson, 2003; OECD, 2004). As seen in the next section, the same holds true when it comes to analysing the economic impact of environmental policies.

\subsection{CGE applications for analysis of environmental policies}

General equilibrium modelling gained in popularity with the first oil shock of the early 1970s. It enabled analysis of the direct effects of policies according to prices, and highlighted certain indirect effects (see Bergman 1991, Winters et al. 1998, Fullerton and Heutel 2007, among others). The research generated a low of discussions on how to model energy policies and their economic impact which are very relevant to today's debates on the modeling of CC policies.

Bergman’s (1991) pioneering work analysed environmental policies in a CGE context, illustrated the importance of capturing general equilibrium effects in this context. In particular, he was careful about distinguishing the winners and losers of such policies. The main problem with his work was the failure to account for microeconomic distributional impacts. Winters et al. (1998) provided an interesting comparative analysis of studies on economic and welfare impacts of climate change on developing countries: Three archetype models representing an Asian, 
African and Latin American country show that these countries suffer on an aggregate basis and low substitution possibilities in Africa lead to the worst effects. Kriström (2006) insists on the importance of this type of modelling in analysing the impact of environmental policies, because, according to him, all markets are independent and only general equilibrium modelling takes into account such interactions. This is even truer in the case of analyses dealing with impacts on welfare, since these models enable the identification of winners and losers and can therefore help establish compensatory policies to attenuate losses.

The concern for environmental pollution included in CGEs was really only scaled up in the 1980s. Most of the studies explored the link between pollution and its economic impacts and population welfare and few explored the impact of environmental policies to address these links. In that context, general equilibrium modelling proved to be a highly effective tool since they allowed to account and discuss the fact that households, producers, governments and the rest of the world all consume energy and are therefore all affected by environmental policies. Bhattacharyya (1996) proposes a classification of applied general equilibrium (AGE) models inspired by that of Schubert (1993) which is in turn based on five categories of modelling traditions:

1) multisectoral growth models (MSG), in the style of Johansen and concerned primarily with the representative agent hypothesis;

2) models very much centered on policy analyses (initially fiscal ones) following the ideas of Scarf (1967) and, Shoven and Whalley (1984);

3) structuralist models based on social accounting matrices (SAM);

4) econometric models in the style of Jorgenson and Wilcoxen (1993a and 1993b); and 
5) intertemporal optimization models following the ideas of Manne and Richels (1977, 1991 and 1994).

In this classification, criteria related to space, periodicity and sectorial disaggregation, as well as the static or dynamic aspect of the model, are all taken into consideration. As Battacharyya (1996) points out, however, it is sometimes difficult to classify models in a single category. For instance, McKibbin and Wilcoxen (1993) build a multiregional (G-cubed) MSG model to analyse environmental policy consequences on growth, international trade and $\mathrm{CO}_{2}$ emissions. Given that the calibration method and representative agent hypothesis both place this model in the MSG category, the disaggregation of the productive sector is reminiscent of the fundamentals of Jorgenson's approach. Among other models developed in the MSG category are the Monash Multi-Regional Forecasting (MMRF-Green) models, descendants of the MONASH and MMF models constructed by the Centre of Policy Studies at Monash University. Most models found in this class are primarily interested in the impacts of GHGs. Some authors, however, attempt to analyse the impact of environmental reform by evaluating costs on physical well-being, so as to test the double-dividend hypothesis. Bye (2000) constructs a intertemporal general equilibrium model for Norway with this goal in mind. Xie and Saltzman (2000) build an "environmental" general equilibrium matrix and model which take into account certain interactions between production and pollution which simulate environmental policies in a developing country, namely China. Fæhn, Gómez-Plana and Kverndokk (2005) also elaborate an environmental model with the objective of analysing the impact of policies aiming to reduce $\mathrm{CO}_{2}$ emissions on the job market. It is important to note, however, that with regards to analysis of the impact of environmental policies, the representative agent hypothesis can prove to be a limitation in this 
type of model, since this sector affects economic agents in different ways (Devarajan and Robinson, 2002).

Given these limitations, models constructed following the ideas of Scarf (1967), Shoven and Whalley (1984) prove to be better adapted to policy impact analysis. The CGE models initiated by Scarf $(1967)$ and Shoven and Whalley $(1973,1984)$ are those found in the literature. The representative agent is replaced by a body of consumers with different initial factor endowments and different preferences, which enables, among other things, analysis of policy impact on the welfare of these agents. Goulder (1982) and Borgess and Goulder (1984) were among the first to build this type of model in order to analyse the impact of energy policies on commerce and economic growth. In the early 1990s, several studies used these models to assess the effects of policies which reduce $\mathrm{CO}_{2}$ emissions. The work of Whalley and Wigle (1991a and 1991b) and Pezzey (1992) in this direction should be noted. These models are dynamic and focus on trade and consequences related to the manner in which taxes are used and emissions are controlled.

André, Cardenete and Velazquez (2005) test the double-dividend hypothesis using a model following the ideas of Scarf, Shoven and Whalley by simulating the impact of different environmental taxes on welfare in Andalusia, Spain. Manresa and Sancho (2005) also test the double-dividend hypothesis using the work of Shoven and Whalley (1984), but assume the existence of a representative agent; they model involuntary unemployment and develop a complex tax system. These authors want to find out whether an environmental tax along with a reduction in income tax could improve the level of employment in Spain. Al-Amin, Jaafar and Siwar (2008) construct a similar model for Malaysia by modifying production technology so as to take emissions into account. They seek to discover what the rate of taxation associated with 
emissions should be, in order to reduce environmental pollution while making sure not to reduce economic growth.

The GEM-E3 is a dynamic computational general equilibrium model initially designed in the mid-1990s for countries belonging to the European Union, in order to establish relationships between the energy sector, environment and economy ${ }^{7}$. It allows one to take into account the accumulation of capital and technological progress, but does not allow an analysis of policy impacts on the job market and related costs. Proost and Van Regemorter (2003) use this model to assess the effects of different policies associated with climate change by disaggregating sectors such as energy, as well as the country (within the European Union). Kouvaritakis, Paroussos and Van Regemorter (2005) analyse the impacts of a tax in the energy sector on European economies as well as on the environment.

Despite the recognized advantages of all these models, they can be criticized in several regards. First, incertitude is not taken into account; it is very difficult to predict with any certainty the reactions of various agents in terms of supply and demand. If the specification proves to be incorrect, the mistake will affect the whole of the model as well as any resulting conclusions. Second, other limits have been highlighted, such as the weakness of empirical validation of parameters and the hypothesis of perfect competition as well as the hypothesis of the absence of rigidity, which are often postulated in CGE models (Battacharyya, 1996).

The third group was initiated by Taylor (1990), who, in his book, claims that his structuralist approach based on Keynesian theory is more appropriate for developing countries and more socially relevant than models following the ideas of Shoven and Whalley $(1973,1984)$. Without seeking to identify a "best" approach, Heady (1991) proposes that the main difference between the two rests in the way they approach the job market. A few structuralist models have

\footnotetext{
${ }^{7}$ Characteristics of the model are available at http://www.gem-e3.net/themodel.htm and http://gem-e3.zew.de/.
} 
been used to study the energy sector, such as those of Panda and Sarkar (1990) or Choucri and Lahiri (1990), who analyse the macroeconomic impact of fuel price fixing in Egypt. According to them, it would be a mistake for domestic markets to adopt global market prices because oil exports are fixed in their model. Heady (1991) also believes that this essentially short-term vision has its limitations. According to him, Taylor (1990) and his followers only model the behaviour of aggregate macroeconomics while leaving out the more microeconomic dimension. For instance, the job market should stabilize with time, rather than at set periods; it also should not be stabilized at the time of reference. Moreover, the way unemployment is modelledcentered on supply—does not reveal what happens to the unemployed, and this is important when it comes to evaluating policy impact. Syrquin (1993) is also critical of this model.

In the fourth group of models, coefficients calculated and fixed using the matrix of intermediary goods are replaced by econometric models that reflect producer behaviours, so as to generate demand functions for inputs in each sector of the economy. The first work done in this direction is that of Hudson and Jorgenson (1974), who analyse the impact of change in energy policy on long-term growth in the United States. In subsequent versions, the household agent is divided into demographic groups according to certain characteristics such as size and area of residence (Jorgenson and Wilcoxen, 1993a). The advantage of this econometric parameterization as opposed to calibration is that it takes the past into account, in order to evaluate production and consumption impacts following price changes of energy goods. It should be noted that technological progress can be considered endogenous. Finally, working with chronological series enables the limitation of effects that can be attributed to data from a particular year (Jorgenson and Wilcoxen, 1993c). The main limitation of this approach concerns the data necessary for parameter assessment. However, some consider that this approach should be seen as 
complimentary rather than as presenting a substitute to the CGE approach in the style of Shoven and Whalley (Berck and Hoffmann 2002).

In intertemporal optimization models - the fifth category of models-the "energy" branch is dealt with differently than other sectors of the economy. According to defenders of this approach, this branch is in fact distinct. A form of technology could substitute one form of energetic input with a completely different one, and a policy in the energy branch could be directly related to a precise type of technology. Manne and Richels (1977) are aware of this and construct an energy technology assessment macro growth (ETA-MACRO) model. The ETAMACRO in the global version (Global 2100) explicitly allows for: 1) energy economy interactions; 2) cost-effective conservation; 3) interfuel substitution, and 4) new supply technologies, each with its own difficulties and uncertainties on dates and rates of introduction. Manne and Richels (1991, 1994), Rutherford (1992), Peck and Teisberg (1993) and Shimazaki, Akisawa and Kashiwagi (2000) have developed different versions of this model. These models have nevertheless been less exploited than those following the ideas of Shoven and Whalley. Schubert (1993) considers that this is due to the impossibility of modelling the imperfections found in markets and to the fact that these models do not allow the simulation of fiscal policies. Battacharyya (1996) considers these models very rich in terms of specification in the energy sector, but criticizes the macroeconomic aggregation done for all of the other sectors. He also points out that, as in the CGE models following the ideas of Shoven and Whalley, these intertemporal optimization models evaluate long-term impacts according to observation from a single point in time.

As Xie and Saltzman (2000) point out, although a number of environmental models have been built in the past twenty years, a good deal of work remains to be done. In addition to the 
absence of environmental data, these authors highlight the fact that existing models were often created for developed countries, while the realities of developing countries are quite different. Moreover, Ekins and Speck (1999) maintains that environmental policies are often treated in terms of efficiency, while the distributional dimension should be considered more often. Labandeira, Labeaga and Rodríguez (2006), among others, note that even if general equilibrium models are highly effective when it comes to analysing the impact of fiscal policies, they do not allow an evaluation of effects on populations from a distributional point of view. For instance, in the tradition of multisectorial models, the presence of a typical consumer in the article by Manresa and Sancho (2005) does not allow analysis of distributional aspects. Distributional impact has been studied recently by a number of authors, however; the following section contains an overview of the few relevant texts found in the literature.

\section{Distributional impact and welfare analysis of environmental policies}

Until very recently, the study of welfare based on general equilibrium models concentrated on the impact on social welfare, notably due to the aggregate nature of the models. This is the case for most CGE models following the ideas of Shoven and Whalley, which were presented in the previous section. Markandya (1998) nevertheless suggests that the analysis of environmental policy impact on income distribution and poverty constitutes an important issue. One way to introduce heterogeneity in household distribution is to define different household groups in such a way as to have one representative agent per group. However, as Labandeira et al. (2004) point out, the number of household groups remains limited, as does the associated distributional analysis. 
Dessus and O'Connor (2003) use a CGE model to analyse reduction of $\mathrm{CO}_{2}$ emissions and health benefits in Chile, and find that the welfare lost is partly offset by health benefits. Timilsina (2007) applies a CGE model to Thailand and analyses various tax instruments used to reduce greenhouse gases, and measures which revenue-recycling scheme produces the weakest welfare lost. O’Ryan, De Miguel, Miller and Munasinghe (2005) start with a static CGE model, ECOGEM-CHILE ${ }^{8}$, and simulate six policies which simultaneously and independently associate social and environmental issues with Chile's economy. The authors use the revenue available per quintile (income-group differentiation) in the model in order to measure the impact of distribution on revenues. These authors, aware of the fact that Chile faces important social and environmental problems, seek to find out whether policies interact in a positive manner or oppose one another. They find that environmental policies related to emissions reductions can have negative social impacts, but that social policies have almost no impact on the environment. As a final point, it seems that the act of concurrently associating a policy of a social nature with an environmental policy could be beneficial, since negative effects can be cancelled out by social measures.

Fullerton and Heutel (2007) build a theoretical general equilibrium model to identify impact distribution of the application of environmental taxes. However, instead of considering the impact in terms of revenues, which generally leads to the conclusion that such taxes are regressive for populations, the authors are interested in the effects on the capital and labour demand by firms. They model pollution as an input similar to capital and labour. Since polluting firms are generally capital-intensive, the authors observe the impact of policies which limit emissions by varying substitution elasticities. As capital and labour are not perfectly complimentary, they conclude that the effect of such a policy will be greater on the richest

\footnotetext{
${ }^{8}$ For a detailed presentation of the model, see O’Ryan, Miller and de Miguel (2003).
} 
households, since (negatively affected) capital payment constitutes an important part of their revenue. The authors therefore conclude that the degree of substitutability between the three factors has important consequences in terms of the analysis of environmental policy impact on income distribution.

Oladosu and Rose (2007) use three arguments to justify the use of CGE models in analysing the impact of environmental policies on income distribution. First, production sectors which release $\mathrm{CO}_{2}$ into the atmosphere, even if few in number, are generally big polluters and produce important externalities on the rest of the economy. Also, the effects of a given emission reduction policy should have significant feedback effects on the whole of the economy. Second, in the context of a partial equilibrium study, it is highly probable that the effect of an emissions tax will be regressive in nature. The absence of substitution possibilities in this context will increase spending, which will directly lead to a decrease in disposable income. Third, in the absence of a CGE model, it would be difficult to measure the impact of an emissions tax if the revenue it generates was used to weaken the discretionary nature of an economy's taxation system. To support these arguments, the authors present ten factors considered in their impact analysis, hence establishing a relationship between an emissions tax and its impact on income distribution $^{9}$. The five simulations retained were selected according to effects of trade, redistribution of tax revenues, tax rates, and tax type, as well as time horizon. The results obtained show that the establishment of a carbon tax will be moderately progressive. These effects on the distribution of income can be observed using nine household groups selected on the basis of their revenues as well as equivalent variation and inequality (Gini index). According to these authors, the results shed new light on the impact of environmental policies on household

\footnotetext{
${ }^{9}$ The model of reference is the one developed by Oladosu (2000) in his doctoral thesis.
} 
income distribution, notably thanks to distinct modelling of revenue and spending, particularly for low-income household groups.

Corong (2008) uses a model similar to that of Oladosu and Rose (2007) to analyse the impact of a carbon tax on the Filipino economy and on the welfare of the Filipino population. He divides the population into six groups of representative agents according to type of employment occupied: 1) government workers; 2) professionals; 3) sales workers; 4) agricultural workers; 5) blue-collar industrial workers; and 6) other households (not classified elsewhere). Using this model, the author simulates different policies related to the imposition of a carbon tax, with or without compensatory measures. Variations in disposable income and prices of consumer goods obtained for the six representative agents are then applied to all households in the Filipino Family Income and Expenditure Survey (FIES-2000). The results show that when the carbon tax is counterbalanced by a reduction of a consumption tax, poverty diminishes and welfare improves.

Yusuf and Resosudarmo (2007, 2008) emphasize the importance of maximizing heterogeneity in the CGE model in order to analyse the distributional impact of environmental policies. To do so, they begin with a model developed by Monash University and the Indonesian Ministry of Energy (INDOCEEM) similar to the MMRF-Green model previously mentioned. Next, following the same procedure as Markandya (1998) and Oladosu and Rose (2007), they bring these household groups into the model. The difference with previous models is that household categories are divided according to expenditure per capita. According to these authors, by increasing the number of household categories (100 centiles in rural settings and 100 more in urban settings), distributional indicators will be much more precise than when the model only uses ten or so groups. The 200 groups are thus fully integrated into the framework of the CGE 
model $^{10}$. Yusuf and Resosudarmo (2007) simulate the establishment of a carbon tax with and without compensatory measures. The first compensatory measure is a decrease in the valueadded tax on consumer goods, while the second simulates a decrease in income tax rate. Their results show that when a carbon tax is progressive for rural households, it does not matter whether the tax is associated to a specific compensatory fiscal policy. This result comes from the fact that poor rural households use comparatively little energy and rising energy prices mean that small-scale farmers who make up the majority of Indonesia's poor and use little machinery could better compete with large farms that rely on high energy consumption machinery. On the other hand, urban household poverty increases, except when the carbon tax is compensated for by a decrease in the income tax rate. Yusuf and Resosudarmo (2008) use the same model, adapting it to simulate increases in fuel prices imposed by the Indonesian government in 2005. In their article, the authors analyse distributional impacts with and without compensatory measures such as money transfers. The measure imposed by the government proves to be regressive for urban households as well as for rural ones when compensatory measures are not applied. However, the compensatory system proposed appears to be beneficial for rural households only, since urban household poverty continues to deepen.

In this group of work, authors seek to display the impact of environmental policies on household income distribution so as to clearly identify whether an environmental measure could have devastating effects on the poorest households. However, while these models concentrate on social and environmental policy impact on distributional aspects, they do not take into account the change in the variance of the income distribution as a whole or of sub-groups of households. Only inter-group redistribution is considered; intra-group changes are left out.

\footnotetext{
${ }^{10}$ Yusuf and Resosudarmo $(2007,2008)$ based their work on the model developed by Warr (2006).
} 
Since the 1990s, however, a large body of literature has emerged which uses CGE modelling for poverty and distributional analysis. The pioneering papers in this line of research include Decaluwé et al. (1999), Cogneau and Robilliard (2000) and Cockburn (2001). These authors have focused in endogenizing the variance of income distribution of the population as a whole or for sub-groups of the population. The general approach proposed is referred to as CGE microsimulation or macro-micro CGE modeling. A large number of applications have been based on these papers ${ }^{11}$. Many analysts have investigated trade reforms (see Hertel and Reimer (2005)), other policy reforms and external shocks. Davis (2004) and Bourguignon and Spadaro (2006) provide interesting literature reviews of macro-micro modelling for distributional impact analysis.

Our review reveals that, in the field of environmental policy, few analyses have been performed using CGE modelling for poverty and distributional analysis to study the distributional impact of CC policies. Labandeira, Labeaga and Rodríguez (2006) have chosen to develop a model based on the approach of Bourguignon, Robilliard and Robinson (2005) to analyse the impact of an energy goods tax on the efficiency of economic sectors and the economy in general, as well as consequences on the welfare of individuals. The advantage of this approach is its ability to obtain differentiated effects of the tax on welfare and income distribution, which the representative agent approach did not allow. In this approach, price and income variations obtained using the CGE model are introduced in an exogenous and sequential manner into a model of energy good demand (microsimulation) to carry out simulations and measure the impact on household income distribution. Labandeira, Labeaga and Rodríguez (2006) take into consideration the fact that the efficiency of environmental policies must go through the price of the energy required to preserve the environment with the substitution of

\footnotetext{
${ }^{11}$ For an interesting review, see Hertel and Reimer (2005).
} 
energy sources. Their CGE model also allows the simulation of $\mathrm{CO}_{2}$ emissions from different energy sources. They simulate a $20 \%$ increase in indirect taxes on consumer energy goods such as electricity, refined products, natural gas and charcoal, and find that the effects on welfare of households grouped in deciles are moderate. This policy proves to be slightly regressive.

Lastly, Arrar, Dissou and Duclos (2008) analyse the intra-group effects of environmental measures in addition to changes between groups within Canada's population; they, too, use a two-step approach. First, using a static multisectorial CGE model, they determine the effects of environmental policies on prices of consumer goods as well as factor payments of production factors. Second, using household survey data, they analyse stochastic dominance. The advantage of this approach is that it does not compel the analyst to choose arbitrarily according to social evaluation (social evaluation function) which can produce biased conclusions. This approach is used increasingly to assess the impact of taxes on distribution and welfare (Yitzhaki and Slemrod, 1991 and Duclos, Makdissi and Wodon, 2008). In this way, the authors assess the impact of price changes on individual and social welfare following the establishment of pollution-control policies, and find that the three policies meant to limit greenhouse gas emissions have negative effects on welfare.

We suggest that combining environmental CGE models that have extensively analyzed the environmental and economic impact of CC mitigation policies with the macro-micro CGE approach for distributional analysis is essential to obtaining a better understanding of distributional incidence of CC mitigation policies and even direct CC impact. 


\section{Policy lessons from existing literature}

Following this literature review, and drawing from the broader literature, we can summarize the lessons learned from OECD countries and developing countries. First, with regards to OECD countries, most of the evidence available from the assessments of individual CC related policies point to their regressivity (See Brännlund and Nordström, 2004; and Creedy and Cornwell, 1997, for examples from Sweden and Australia, respectively). This result holds for a very wide range of instruments, although it seems to be more of a problem for energy taxes than for other taxes. A strong determinant of this regressivity is the considerable substitution between capital and labour observed in many sectors of developed economies. The poor also tend to be relatively more harshly penalized by these policies the higher the degree of substitution between pollution and employment. According to Fullerton and Heutel (2007), most studies concluding on the regressivity of CC policies focus on the direct expenditure impact of these policies.

The available research also shows that the regressivity of CC policies can be offset (see Labandeira, Labeaga and Rodríguez (2006)). Recycling revenue from CC based taxes and permits seems to be a very effective solution, but it would also require an income tax system reform, which would be central to achieving progressivity. Creating jobs is another option in terms reducing the regressivity of CC policies (a double dividend). Investing the revenue from CC tax instruments in infrastructure biased towards the needs of the poorest is a third option for offsetting the regressivity of these taxes. A final way in which CC policies can end up reducing regressivity is by ensuring that the benefits of the CC policies are biased in favour of the poorest. Assessing the average progressivity of these policies is however quite difficult, since their impact 
needs to be addressed at the project level and project data is often hard to aggregate to get a sense of the average.

When it comes to lessons from developing countries, there are significantly fewer distributional incidence analyses of CC policies than there are for developed countries. Our review of the literature identified published case studies for Chile only. All generally confirm the regressive nature of most instruments observed in OECD countries. O’Ryan et al. (2005) find that the regressive nature of CC policies can be attenuated by progressive social policies that have no negative environmental impact in Chile. Similarly, Corong (2008) finds that a carbon tax combined with a reduction in sales tax can be progressive in the Philippines. For their part, Yusuf and Resosudarmo (2007) find that a carbon tax is progressive for rural households but a compensating reduction in sales tax is required for the carbon tax to be progressive for urban households.

The main differences between developed and developing countries are of two types; both imply significant additional burdens on the poor associated with standard CC policies.

The first is driven by the adjustment and transition costs for the poor as workers. Transitional labour market arrangements as industries adopt new technologies can be quite painful, as was the case with the initial job losses or job displacements associated with the introduction of Brazil's large-scale proalcohol program intended to reduce dependence on traditional fuels. Changes in the relative prices of agricultural products associated with CC policies may also change comparative advantages and hence production structure towards more capital-intensive productions. Finally, changes in production location within countries or across countries can be much more harmful in poor countries than in OECD countries. 
The second set of drivers of major differences in the distributional outcome of CC policies is the increased risk for the poor as consumers. Some of the specific sources of added tension identified include the higher cost of basic nutritional sources (i.e. the debate on the use of corn for biofuels rather than for food in Mexico) and the tendency of CC policies to favour urban consumers over rural ones.

\section{Conclusions}

The models used to assess the incidence of CC policies in developed countries have certain limitations when applied to developing countries. First, standard models often assume competitive pricing and constant returns to scale, but these are not typical in many key industries (i.e. energy) which are therefore regulated. The outcome is that these models underestimate the progressivity of CC price-based policies intended in regulatory design but may underestimate the regressivity associated with rationing when service coverage is an issue. Second, these models often assume downward supply curves. This is not always the case for key industries associated with CC. This is particularly an issue in developing countries where industry-specific capital or dependence on a scarce natural resource is common. This also results in underestimates of the progressivity of CC policies, since the assumption implies lower rents rather than higher prices.

Third, for developing countries, these models often fail to reflect that the agricultural sector is a major employer as well as a major supplier of local foods, which can become major tradable goods under global CC policies (i.e. biofuels). There is thus more uncertainty on incidence. Moreover, adapted distributional analysis is needed to capture the impact of CC policies based on the specificity of the agricultural sector in a given country. Fourth, these models tend to ignore that composition of supply may change significantly as a result of global 
changes (such as trade) driven by carbon footprint. Once more, there is more uncertainty on supply effects and hence on derived demand for labour, including that of the less skilled. The local incidence of global CC policies thus tends to be underestimated.

Fifth, the models often ignore that subsidies to water, energy and transport services are regressive in their current design. Thus, they tend to overestimate the regressivity of certain subsidy reductions.

Sixth, developing countries tend to ignore the fact that large shares of their populations are served by informal markets and the agricultural sector, where carbon taxes tend to affect more capital-intensive sectors (Yusuf and Resosudarmo (2007)). Since neither supply nor demand are currently well measured, any progressivity may be overestimated because it fails to take into account the informal economy.

Seventh, most of the models fail to offer joint assessments of the distributional effects of benefits, income and expenditures associated with CC policies. This implies that apparently regressive effects of CC policies on prices may be progressive once expenditure policies are accounted for. Eighth, the production structures of developing countries are less uniform than those of developing countries; some are net importers of energy or agricultural goods, while others are net exporters. These differences should preclude the generalization of conclusions. Ninth, the intensity of energy consumption can be much lower in developing economies (Yusuf and Resosudarmo (2007)), which can lead to overestimating the regressivity of carbon taxes.

There are clearly many more reasons why it is difficult to identify whether models overestImate any intended progressivity of CC policies or underestimate their regressivity. For instance, ignoring enforcement costs or problems, ignoring differences in demand elasticities across income groups or ignoring the differences in expenditure and income structures across 
income groups can all result in misleading diagnostics. Incidence analyses are yet to account for these dimensions.

Overall, however, none of these limitations seem to significantly devaluate the broad analytical case for the need to conduct more systematic incidence analysis of the CC policies being considered. Labandeira, Labeaga and Rodríguez (2006) emphasize the importance of the micro modelling of household behaviour for a rigorous distributional analysis and Fullerton and Heutel (2007) demonstrate the importance of a CGE framework to capture the key price and income effects of CC policies. As suggested by Yusuf et al. (2007), we conclude that the ideal framework for analysing the distributional impact of CC policies is a CGE macro-micro simulation approach as proposed by various authors and as stated in the two literature reviews previously referred to. Bourguignon and Savard (2008) review different approaches and any of these macro-micro simulation CGE approaches would be an appropriate tool. The definite choice of a methodology essentially depends on the data and time constraints faced by the modellers. Moreover, the above suggestion should be integrated in an ideal modelling exercise. However, a standard distributional impact analysis might not address each of these issues. The modeller should consider the trade-offs of the marginal contribution of each element and the marginal change this will contribute to their findings. This is a difficult exercise to perform in an ex ante mode, but experienced modellers can make this judgement call relatively easily before embarking on new applications. 


\section{References}

Al-Amin, A. Q., Jaafar, A. H. and Siwar, C., (2008), "A Computable General Equilibrium Approach To Trade And Environmental Modelling In The Malaysian Economy," MPRA Paper 8772, University Library of Munich, Germany.

André F. J., M. A. Cardenete and E. Velázquez, (2005), "Performing an environmental tax reform in a regional economy. A computable general equilibrium approach" The Annals of Regional Science, vol. 39(2), pages 375-392.

Araar, A., Y. Dissou and J.-Y. Duclos, (2008), "Household Incidence of Pollution Control Policies: a Robust Welfare Analysis Using General Equilibrium Effects”, Cahier de recherché du CIRPEE \#08-09.

Berck P., and S. Hoffmann, (2002), “Assessing the Employment Impacts of Environmental and Natural Resource Policy”, Environmental and Resource Economics, v22(n1-2), 133-56.

Bergman L., (1991), "General Equilibrium Effects of Environmental Policy: A CGE-Modeling Approach", Environmental and Resource Economics Vol1, pp 43--61.

Bhattacharyya S. C., (1996), “Applied general equilibrium models for energy studies: a survey”, Energy Economics, Volume 18, Issue 3, 145-164.

Boccanfuso, D. A. Estache, L. Savard (2008a) Impact Analysis of Electricity reforms in Mali: A Macromicro analysis, forthcoming in South African Journal of Economics.

Boccanfuso, D. A. Estache, L. Savard (2008b) Impact Analysis of Electricity reforms in Senegal: A Macro-micro analysis forthcoming in Journal of Development Studies.

Borgess A. and L.H. Goulder, (1984), "Decomposing the impact of higher energy prices on long-term growth", in Herbert E. Scarf and John B. Shoven (eds.), Applied General Equilibrium Analysis, Cambridge University Press., Cambridge.

Bourguignon F., Robilliard, A. S. and Robinson, S. (2005) Representative Versus Real Households in the Macroeconomic Modeling of Inequality. In T. J. Kehoe, T.N. Srinivasan, and J. Whalley (eds.), Frontiers in Applied General Equilibrium Modeling. Cambridge: Cambridge University Press.

Bourguignon, F., and A. Spadaro (2006) "Microsimulation as a Tool for Evaluating Redistribution Policies ”, Journal of Economic Inequality, 4 (1); 77-106.

Bourguignon, F. and L. Savard (2008). A CGE Integrated Multi-Household Model with Segmented Labor Markets and unemployment in Bourguignon, F., L.A. Pereira Da Silva and M. Bussolo, eds. "The Impact of Macroeconomic Policies on Poverty and Income Distribution: Macro-Micro Evaluation Techniques and Tools" Palgrave-Macmillan Publishers Limited, Houndmills.

Brännlund, R. and Nordström, J. (2004). Carbon Tax Simulations Using a Household Demand Model. European Economic Review, Vol. 48, no 1, pp. 211-233.

Bulmer-Thomas, V., (1982), "Input-output analysis in developing countries: sources, methods and applications", New York. John Wiley \& Sons, 297 p. 
Bye B. (2000), "Environmental tax reform and producer foresight: An intertemporal computable general equilibrium analysis”, Policy Modelling 22(6): 719-752.

Cazorla, M. and M. Toman. (2000) International Equity and Climate Change Policy, RFF Climate Issue Brief No. 27, Washington.

Choucri and Lahiri, 1990. N. Choucri and S. Lahiri, Short-run energy-economy interactions in Egypt. In: Lance Taylor, Editor, Socially Relevant Policy Analysis: Structuralist Computable General Equilibrium Models for the Developing World, MIT Press, Cambridge, MA (1990).

Cockburn, J. (2001), «Trade liberalization and Poverty in Nepal: A Computable General Equilibrium Micro-simulation Analysis », Cahier de recherche 01-18. CREFA, Université Laval.

Cogneau, D. and Robilliard, A.S. (2000) Income Distribution, Poverty and Growth in Madagascar: Micro Simulations in a General Equilibrium Framework. IFPRI TMD Discussion Paper 61, International Food Policy Research Institute, Washington, DC.

Cornwell A. and J. Creedy, (1996), "Carbon taxation, prices and inequality in Australia”, Fiscal Studies, vol. 17, no. 3, pp. 39-61.

Corong E. L., (2008), “Tariff Reductions, Carbon Emissions, and Poverty: An Economy-wide Assessment of the Philippines”, ASEAN Economic Bulletin - Volume 25, Number 1, pp. 20-31.

Creedy, J. and Cornwell, A. (1997) Measuring the welfare effects of price changes using the LES, with an application to a carbon tax. Empirical Economics, 22, pp. 589-613.

Davis, J. B. (2004) «Microsimulation, CGE and Macro Modelling for Transition and Developing Economies », article présenté au Congrès UNU/WIDER, Helsinki.

Decaluwé, B. Dumont, J.C. and Savard, L. (1999) How to Measure Poverty and Inequality in General Equilibrium Framework. Working Paper 9920, CREFA, University of Laval, Québec.

Department for International Development-DFID, (2004), Climate Change in African, Key Sheets \# 10, DFID, London, U.K.

Dessus, S. and D. O’Connor (2003), Climate Policy without Tears: CGE-Based Ancillary Benefits Estimates for Chile, Environmental and Resource Economics. vol. 25: pp. 287-317.

Devarajan S. and S. Robinson, (2002), "The influence of computable general equilibrium models on policy," TMD discussion papers 98, International Food Policy Research Institute (IFPRI).

Doornbosch, R., and R. Steenblik, (2007), Biofuels: is the cure worse than the disease, background paper prepared for the $20^{\text {th }}$ meeting of the Round Table on Sustainable Development, OECD, Paris.

Duclos, J.-Y., P. Makdissi, and Q. Wodon, (2008): “Socially-Improving Tax Reforms,” International Economic Review, Vol. 49, No. 4, pp. forthcoming.

Ekins, P. and S. Speck, (1999). "Competitiveness and Exemptions From Environmental Taxes in Europe," Environmental \& Resource Economics, vol. 13(4), pages 369-396. 
Fæhn T., A. G. Gómez-Plana and S. Kverndokk, (2005), "Can a carbon permit system reduce Spanish unemployment?", Discussion Papers 410, Research Department of Statistics Norway.

Fullerton, D. and G. Heutel (2007), The general equilibrium incidence of environmental taxes, Journal of Public Economics Vol. 91, no. 3-4, pp. 571-591.

Goulder L.H., (1982), “A General Equilibrium Analysis of US Energy Policies”, Ph.D dissertation, Stanford University.

Heady C., (1991), Reviewed work(s): Socially Relevant Policy Analysis: Structuralist Computable General Equilibrium Models for the Developing World by Lance Taylor, The Economic Journal, Vol. 101, No. 409, pp. 1584-1585.

Hertel, T. and Reimer, J. (2005) Predicting the poverty impacts of trade reform, Journal of International Trade \& Economic Development, 14(4), pp. 377-405.

Hudson, E. A. and D.W. Jorgenson, (1974), “US energy policy and economic growth, 1975-2000”, The Bell Journal of Economics and Management Science, 5, 461-514.

IPCC, 2007: Climate Change 2007: Impacts, Adaptation and Vulnerability. Contribution of Working Group II to the Fourth Assessment Report of the Intergovernmental Panel on Climate Change, M.L. Parry, O.F. Canziani, J.P. Palutikof, P.J. van der Linden and C.E. Hanson, Eds., Cambridge University Press, Cambridge, UK, 976pp.

Isard W., C. L. Choquill, J. Kissin, R. H. Seyfarth and R. Tatlock (1972), Ecologic-Economic Analysis for Regional Development. New York: The Free Press.

Ivanic, M., and W. Martin (2007) "Implications of Higher Global food Prices for Poverty in Low-Income Countries” Policy Research Working Paper 4594, World Bank, Washington, DC.

Johansson, P.O. (1993), Cost-Benefit Analysis of Environmental Change, Cambridge: Cambridge University Press.

Jorgenson D.W. and P.J. Wilcoxen, (1993a), "Reducing US carbon emissions: An econometric general equilibrium assessment”, Resource and Energy Economics, 15, 7-25.

Jorgenson D.W. and P.J. Wilcoxen, (1993c), “Energy Prices, Productivity, and Economic Growth”, Annual Review of Energy and Environment, 18, 343-395.

Jotzo, F. (2004): .Developing countries and the future of the Kyoto Protocol,. Economics and Environment Network Working Papers 0406, Australian National University, Economics and Environment network,

Kouvaritakis, N., Paroussos, L., Van Regemorter, D., 2003. The macroeconomic evaluation of energy tax policies within the EU, with the GEM-E3-Europe model. Final Report of the Study for the European Commission, TAXUD/2002/DE/302.

Kriström, B. (2006), Framework for assessing the distribution of financial effects of environmental policy, in Eds, Ysé Serret and Nick Johnstone, The Distributional Effects of Environmental Policy, Edward Elgar, Cheltenham, UK. 
Labandeira X., J.M. Labeaga, (1999), “Combining input-output analysis and micro-simulation to assess the effects of carbon taxation on Spanish households”, Fiscal Studies, 20 (3), 303-318.

Labandeira X., J.M. Labeaga and M. Rodríguez, (2004), “Green tax reforms in Spain”, European Environment, Vol 14, pp 190-299.

Labandeira X., J.M. Labeaga and M. Rodríguez, (2006), “A Macro and Microeconomic Integrated Approach to Assessing the Effects of Public Policies”, Documento de Trabajo 02-2006, FEDEA; Working Paper 22, ECINEQ.

Leontief, W. (1970), "Environmental Repercussions and Economic Structure: An Input-Output Approach”, Review of Economics and Statistics 52, 262-271.

Manne A.S. and R.G. Richels, (1977), “ETA-MACRO: A model of energy-economy interaction”, in J. Hitch, (ed.), Modeling Energy-Economy Interactions: Five Approaches, Research paper No. 5, Resources for the Future, Washington, DC.

Manne A.S. and R.G. Richels, (1991), "Global $\mathrm{CO}_{2}$ emission reductions: the impacts if rising energy costs”, The Energy Journal, 12, 87-107.

Manne A.S. and R.G. Richels, (1994), "The costs of stabilizing global CO 2 emissions: a probablistic model based on expert judgements”, The Energy Journal, 15, 31-76.

Manresa A and F. Sancho, (2005), "Implementing a double dividend: Recycling ecotaxes toward lower labor taxes”, Energy Policy, 33: 1577-1585.

Markandya A., (1998), "Poverty, Income Distribution and Policy-making”, Environmental and Resource Economics, 11, (3-4), 459-472.

McCulloch, N., A. Winters and X. Cirera (2002) Trade Liberalization and Poverty: A Handbook, London: Centre for Economic Policy Research and Department for International Development.

McKibbin W.J. and P.J. Wilcoxen, (1993),’'The global consequences of regional environmental policies: an integrated macroeconomic, multi-sectoral approach.” In: Kaya, Nakicenovic, Nordhaus and Toth, Editors, Costs, Impacts and Benefits of $\mathrm{CO}_{2}$ Mitigation, IIASA, Austria.

Miller, R. and P. Blair, (1985), "Input-output analysis: Foundations and extensions", Englewood Cliffs, NJ : Prentice-Hall, Inc.

OECD, (2004), "Environment and Distributional Issues: Analysis, Evidence and Policy Implications », OECD programme on the "Social and Environment Interface".

Oladosu, G. (2000), “A non-market computable general equilibrium model for economic analysis of climate change in the Susquehanna River Basin”, PhD Thesis, Department of Energy, Environmental, and Mineral Economics, Pennsylvania State University, University Park, PA.

Oladosu G. and A. Rose, (2007), "Income distribution impacts of climate change mitigation policy in the Susquehanna River Basin economy”, Energy Economics, Vol 29, pp 520-544. 
O’Ryan, R., S. Miller and C. J. de Miguel, (2003), “A CGE framework to evaluate policy options for reducing air pollution emissions in Chile”, Environment and Development Economics, Vol 8, pp 285309.

O’Ryan R., C. J. De Miguel, S. Miller and M. Munasinghe, (2005), “Computable general equilibrium model analysis of economywide cross effects of social and environmental policies in Chile", Ecological Economics, Vol 54, pp 447-472.

Oxfam, (2007) Bio-fuelling Poverty Why the EU renewable-fuel target may be disastrous for poor people, Oxfam Briefing notes, Oxford, U.K.

Pan, X. and S. Kraines (2001), "Environmental Input-Output Models for Life-Cycle Analysis”, Environmental and Resource Economics 20, 61-72.

Panda M.K. and H. Sarkar , Resource mobilisation through administered prices in an Indian CGE. In: L. Taylor, Editor, Socially Relevant Policy Analysis: Structuralist Computable General Equilibrium Models for the Developing World, The MIT Press, Cambridge MA (1990).

Peck S.C. and T.J. Teisberg, (1993), "Global warming uncertainties and the value of information: an analysis using CETA”, Resource and Energy Economics, 15, 71-97.

Pezzey J. (1992), Analysis of unilateral $\mathrm{CO}^{2}$ control in the European Community and OECD, The Energy Journal, 13, 159-171.

Proost S. and D. Van Regemorter, 2003. "Climate change policy in European countries and its effects on industry," Energy, Transport and Environment Working Papers Series ete0305, Katholieke Universiteit Leuven, Centrum voor Economische Studiën, Energy, Transport and Environment.

Roson R., (2003), “Climate change policies and tax recycling schemes: Simulations with a dynamic general equilibrium model of the Italian economy”, of Urban \& Regional Development Studies, Vol 15(1), 26-44.

Rutherford, T. 1992, The Welfare Effects of Fossil Carbon Restrictions: Results from a Recursively Dynamic Trade Model, OECD Working Papers, No 112, OECD, Paris.

Scarf H. E. (1967), "On the Computation of Equilibrium Prices", in W. FelIner et al., Ten Economic Studies in the Tradition of Irving Fisher (New York: John Wiley and Sons, Inc.)

Schubert, K., (1993), « Les modèles d'équilibre général calculable: Une revue de la littérature », Revue d'Économie Politique. v103(n6), 775-825.

Serret, Y. and N. Johnstone (2006), The Distributional Effects of Environmental Policy, Edward Elgar, Cheltenham, UK, 323 pages.

Shimazaki Y., A. Akisawa and T. Kashiwagi, (2000), “A model analysis of clean development mechanisms to reduce both CO2 and SO2 emissions between Japan and China”, Applied Energy Volume 66, Issue 4, Pages 311-324.

Shoven, J. and Whalley, J. (1973): "A General Equilibrium with Taxes: A Computational Procedure and an Existence Proff". Review of Economics Studies, 40, pp 475-495. 
Shoven J. and J. Whalley, (1984), “Applied general equilibrium models of taxation and international trade: an introduction and survey”, Journal of Economic Literature, 22, 1007-1051.

Symons, E., J. L. Proops and P. Gay, (1994), "Carbon taxes, consumer demand and carbon dioxide emissions: a simulation analysis for the UK”, Fiscal Studies, vol. 15, no. 2, pp. 19-43.

Syrquin, M. (1993), Reviewed work(s): Socially Relevant Policy Analysis: Structuralist Computable General Equilibrium Models for the Developing World by Lance Taylor, Economic Development and Cultural Change, Vol. 42, No. 1, pp. 193-198.

Taylor, L., (1990), Socially Relevant Policy Analysis: Structuralist Computable General Equilibrium Models for the Developing world, The MIT Press.

Timilsina, G. R., (2007). "Atmospheric stabilization of CO2 emissions : near-term reductions and intensity-based targets," Policy Research Working Paper Series 4352, The World Bank

Tol, R. S. J. (2001) Equitable cost-benefit analysis of climate change policies, Ecological Economics 36 (2001) pp. 71-85.

Tol, R. S.J, T. E. Downing, O. J. Kuik, J. B. Smith, (2004), Distributional aspects of climate change impacts, Global Environmental Change, Vol. 14, pp. 259-272.

Toman, M. A. and D. Burtraw, (1992), Equity and International Agreements for $\mathrm{CO}_{2}$ Containment, Journal of Energy Engineering, Vol. 118, No. 2, pp. 122-135.

United Nation Development Programme-UNDP (2007), Human Development Report, Fighting Climate Change: Human Solidarity in a Divided World, Palgrave-Macmillen, New York. 384 pages.

Verbruggen H., O. Kuik, and M. Bennis, (1995), "Environmental Regulations as Trade Barriers for Developing Countries: Eco-labelling and the Dutch Cut Flower Industry”, CREED Working Paper No 2.

Warr P., (2006), "The Gregory Thesis Visits the Tropics." Economic Record 82(257), pp 177-194.

Whalley J. and R. Wigle, (1991a), “Cutting CO 2 emissions: the effects of alternative policty approaches”, The Energy Journal, 12, 109-124.

Whalley J. and R. Wigle, (1991b), “The international incidence of carbon taxes”, in R. Dornbusch and J. Poterba (eds.), Economic Policy Responses to Global Wanning, MIT Press, Cambridge, MA.

Wier M., K. Birr-Pedersen, H. Klinge Jacobsen and J. Klok, (2005), “Are CO2 taxes regressive? Evidence from the Danish experience”, Ecological Economics, Volume 52, Issue 2, Pages 239-251.

Winters, P, R. Murgai, E. Sadoulet, A. de Janvry, and G. Frisvold (1998), Economic and Welfare Impacts of Climate Change on Developing Countries, Environmental and Resource Economics Vol. 12, pp. 1-2.

Wodon, Q., C. Tsimpo, P. Backiny-Yetna, G. Joseph, F. Adoho, and H. Coulombe (2008), "Impact of Higher Food Prices on Poverty in West and Central Africa” mimeo, World Bank, Washington, DC.

Xie J. and S. Saltzman, (2000), "Environmental policy analysis: An environmental computable general equilibrium approach for developing countries”. Journal of Policy Modelling, 22(4): 453-489. 
Yitzhaki, S. and J. Slemrod, (1991): “Welfare Dominance: An Application to Commodity Taxation,” American Economic Review, LXXXI, pp 480-96.

Yusuf A. A. and B. P. Resosudarmo, (2007), "On the Distributional Effect of Carbon Tax in Developing Countries: The Case of Indonesia", Working Papers in Economics and Development Studies (WoPEDS) 200705, Department of Economics, Padjadjaran University.

Yusuf A. A. and B. P. Resosudarmo, (2008), "Mitigating Distributional Impact of Fuel Pricing Reform: The Indonesian Experience”, ASEAN Economic Bulletin - Volume 25, Number 1, pp. 32-47. 